\title{
Effects of dietary supplementation of probiotic, Clostridium butyricum, on growth performance, immune response, intestinal barrier function, and digestive enzyme activity in broiler chickens challenged with Escherichia coli K88
}

Ling Zhang ${ }^{1,2}$, Lingling Zhang ${ }^{2}$, Xiu'an Zhan ${ }^{1}$, Xinfu Zeng ${ }^{3}$, Lin Zhou' ${ }^{1}$ Guangtian Cao ${ }^{1}$, An'guo Chen ${ }^{1}$ and Caimei Yang ${ }^{2^{*}}$

\begin{abstract}
Background: Colibacillosis caused by enterotoxigenic Escherichia coli (E. coli) results in economic losses in the poultry industry. Antibiotics are usually used to control colibacillosis, however, E. coli has varying degrees of resistance to different antibiotics. Therefore the use of probiotics is becoming accepted as an alternative to antibiotics. In this study, we evaluated the effects of Clostridium butyricum (C. butyricum) on growth performance, immune response, intestinal barrier function, and digestive enzyme activity in broiler chickens challenged with Escherichia coli (E. coli) K88.

Methods: The chickens were randomly divided into four treatment groups for 28 days. Negative control treatment (NC) consisted of birds fed a basal diet without E. coli K88 challenge and positive control treatment (PC) consisted of birds fed a basal diet and challenged with E. coli K88. C. butyricum probiotic treatment (CB) consisted of birds fed a diet containing $2 \times 10^{7} \mathrm{cfu}$ C. butyricum $/ \mathrm{kg}$ of diet and challenged with E. coli K88. Colistin sulfate antibiotic treatment (CS) consisted of birds fed a diet containing $20 \mathrm{mg}$ colistin sulfate/kg of diet and challenged with E. coli K88.

Results: The body weight (BW) and average day gain (ADG) in the broilers of $C B$ group were higher $(P<0.05)$ than the broilers in the PC group overall except the ADG in the 14-21 d post-challenge. The birds in CB treatment had higher $(P<0.05)$ concentration of tumor necrosis factor-a (TNF-a) at 3 and $7 \mathrm{~d}$ post-challenge, and higher $(P<0.05)$ concentration of interleukin-4 (IL-4) at $14 \mathrm{~d}$ post-challenge than those in the $\mathrm{PC}$ treatment group. The concentration of serum endotoxin in CB birds was lower $(P<0.05)$ at $21 \mathrm{~d}$ post-challenge, and the concentrations of serum diamine oxidase in $C B$ birds were lower $(P<0.05)$ at 14 and $21 \mathrm{~d}$ post-challenge than in $P C$ birds. Birds in $C B$ treatment group had higher $(P<0.05)$ jejunum villi height than those in $P C, N C$, or CS treatment at 7,14 , and 21 d post-challenge. In comparison to $P C$ birds, the $C B$ birds had lower $(P<0.05)$ jejunum crypt depth during the whole experiment. The birds in $\mathrm{CB}$ or $\mathrm{CS}$ treatment group had higher $(P<0.05)$ activities of amylase and protease at 3,7 , and $14 \mathrm{~d}$ post-challenge, and higher $(P<0.05)$ activity of lipase at 3, 7 d post-challenge than $P C$ birds.

(Continued on next page)
\end{abstract}

\footnotetext{
*Correspondence: yangcaimei2012@163.com

${ }^{2}$ College of Animal Science and Technology, Zhejiang A \& F University, 88

North Huancheng Road, Lin'an, Zhejiang 311300, China

Full list of author information is available at the end of the article
} 
(Continued from previous page)

Conclusions: In all, these results indicate that dietary supplementation with C. butyricum promotes immune response, improves intestinal barrier function, and digestive enzyme activities in broiler chickens challenged with E. coli K88. There is no significant difference between the $C$. butyricum probiotic treatment and the colistin sulfate antibiotic treatment. Therefore, the C. butyricum probiotic may be an alternative to antibiotic for broiler chickens.

Keywords: Broiler chickens, Clostridium butyricum, Digestive enzyme activity, Escherichia coli K88, Growth performance, Immune response, Intestinal barrier

\section{Background}

Colibacillosis caused by enterotoxigenic Escherichia coli (E.coli) is a serious infection that results in huge economic losses in the poultry industry worldwide [1-4]. Although antibiotics are usually used to control colibacillosis, various reports have demonstrated that pathogenic $E$. coli has varying degrees of resistance to different antibiotics [5, 6]. Additionally, resistance genes extended-spectrum beta-lactamases (ESBL) and/or plasmid-mediated Amp-C beta-lactamases (Amp-C) in commercial E. coli may pose a human health hazard. [7] Therefore, there is an urgent need to identify sustainable alternatives to antibiotics for animal production.

The use of probiotics in the poultry industry is quickly becoming accepted as a potential alternative to antibiotics for use as growth-promoters, and in some cases, for control of specific enteric pathogens [8-15].

Clostridium butyricum (C. butyricum) is a butyricacid producing Gram-positive anaerobe found in soil and intestines of healthy animals and humans. $C$. butyricum increases the concentrations of n-butyric acid in caecaldigesta of birds [16], and butyric acid is of particular importance because of its nutritional properties for epithelial cells and pathogen inhibitory effects in the gut [17]. C. butyricum also survives at low $\mathrm{pH}$ and high temperature, which renders it a good feed additive [18]. Previous studies demonstrated that $C$. butyricum promoted growth performance $[16,19-21]$, balanced intestinal microflora $[16,17,19,20]$, improved intestinal morphology $[16,19]$, stimulated the immune system $[19,20]$, improved meat quality and fatty acid profiles [21-23], and influenced the digestive tract [23] in broiler chickens. In addition, C. butyricum prevented E.coliinduced intestinal disorders through inhibiting E.coli viability and mediating E.coli-induced apoptosis [24]. However, there are few published reports on the effects of C. butyricum on E.coli-challenged animals. The present study was conducted to investigate the effects of C. butyricum on the immune response, intestinal barrier function, and digestive enzyme activities in broiler chickens challenged with E. coli K88.

\section{Methods}

\section{Ethics statement}

All procedures were approved by the Institutional Animal Care and Use Committee of Zhejiang University.

\section{Birds, diets, and experimental design}

Three hundred and sixty 1-d-old male Cobb broiler chickens purchased from a commercial hatch (Charoen Pokphand Group, Haining, China) were randomly assigned to four treatment groups. Negative control treatment $(\mathrm{NC})$ consisted of birds fed a basal diet without challenging with E. coli K88. Positive control treatment $(\mathrm{PC})$ consisted of birds fed a basal diet and orally challenged with $0.5 \mathrm{~mL}$ E. coli $\mathrm{K} 88\left(2 \times 10^{8} \mathrm{cfu} / \mathrm{mL}\right)$ on d 7. The C. butyricum treatment (CB) probiotic group consisted of birds fed a diet containing $2 \times 10^{7} \mathrm{cfu} C$. butyricum $/ \mathrm{kg}$ of diet and orally challenged with $0.5 \mathrm{~mL}$ E. coli $\mathrm{K} 88\left(2 \times 10^{8} \mathrm{cfu} / \mathrm{mL}\right)$ on d 7 . Colistin sulfate treatment (CS) antibiotic group consisted of birds fed a diet containing $20 \mathrm{mg}$ colistin sulfate $/ \mathrm{kg}$ of diet and orally challenged with $0.5 \mathrm{~mL}$ E. coli $\mathrm{K} 88\left(2 \times 10^{8} \mathrm{cfu} / \mathrm{mL}\right)$ on d 7. Each treatment consisted of 6 replicate pens with 15 birds per pen. Birds in NC treatment were housed in one room, while the birds in other three E. coli-challenged treatment groups were housed in another room to prevent cross-contamination. The two rooms were of the same configuration and the previous growth studies revealed no significant contamination room effects.

Chickens were placed in the wire cages and all birds were offered the same antibiotic-free basal diets and provided ad libitum access to water and diet. The nutrient levels of the diets met the NRC (1994) broiler recommendations (Table 1). The temperature was adjusted to $32{ }^{\circ} \mathrm{C}$ in the first week and gradually lowered to $25^{\circ} \mathrm{C}$.

The C. butyricum strain (HJCB998) was obtained from Zhejiang Huijia Biological Technology Ltd., Anji, China. The probiotic strain was grown anaerobically in a liquid fermentation tank at $37{ }^{\circ} \mathrm{C}$ for $48 \mathrm{~h}$, and then the cells were harvested by centrifugation and dried by spray-drying technology. Colistin sulfate was obtained from Zhejiang Qianjiang Biochemical Ltd., Haining, China. 
Table 1 The composition and nutrients of basal diet ${ }^{\mathrm{a}}$

\begin{tabular}{llll}
\hline Ingredient & Content, \% & Chemical composition & Content \\
\hline Corn & 55.23 & CP, \% & 20.90 \\
Soybean meal & 30.67 & ME, Mcal/kg & 3.00 \\
Wheat shorts & 4.00 & Calcium, \% & 1.00 \\
Fish meal $^{b}$ & 3.00 & Total P, \% & 0.65 \\
Soybean oil $^{c}$ & 2.90 & Available P, \% & 0.45 \\
DL-Methionine & 0.27 & Methionine + & 0.90 \\
& & cysteine, \% & \\
NaCl & 0.27 & Lysine, \% & 1.05 \\
Limestone $_{\text {Calcium phosphate }}$ & 1.33 & & \\
Vitamin-mineral premix & & \\
\hline
\end{tabular}

${ }^{a}$ Nutrient level of the diets was based on NRC (1994)

${ }^{\mathrm{b}}$ Crude protein content is $62.5 \%$ and metabolizable energy is $2.79 \mathrm{Mcal} / \mathrm{kg}$

${ }^{\mathrm{C}}$ Metabolizable energy is $8.8 \mathrm{Mcal} / \mathrm{kg}$

${ }^{\mathrm{d}}$ Supplied per kilogram of diet: vitamin A(retinyl acetate), 1,500 IU;

cholecalciferol, $200 \mathrm{IU}$; vitamin E(DL-a-tocopheryl acetate), $10 \mathrm{IU}$; riboflavin, 3.5

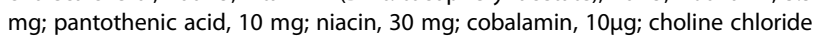

$1,000 \mathrm{mg}$; biotin, $0.15 \mathrm{mg}$; folic acid, $0.5 \mathrm{mg}$; thiamine $1.5 \mathrm{mg}$; pyridoxine 3.0

mg; Fe, 80 mg; Zn, 40 mg; Mn, 60 mg; l, 0.18 mg; Cu, 8 mg; Se, 0.15 mg

\section{Oral challenge}

The E. coli K88 strain was obtained from College of Animal Sciences, Zhejiang University (Hangzhou, China) and grown at $37{ }^{\circ} \mathrm{C}$. The birds in different treatments were fed the corresponding diet for the first $6 \mathrm{~d}$. On $\mathrm{d} 7$, birds in $\mathrm{PC}, \mathrm{CB}$, and CS treatments were orally fed with $0.5 \mathrm{~mL}\left(2 \times 10^{8} \mathrm{cfu} / \mathrm{mL}\right)$ E. coli $\mathrm{K} 88$ inoculants by using a polyethylene tube attached to a syringe. The birds in NC treatment were administered the same amount of sodium chloride solution as control.

\section{Sample collection}

Birds were weighed individually at $3,7,14$, and $21 \mathrm{~d}$ post-challenge to evaluate BW and ADG. Feed consumption and feed-to-gain ratio could not be determined because of an indeterminate amount of feed wastage.

Six birds per treatment (1 bird per pen) were randomly selected for sample collection at 3, 7, 14, and 21 $\mathrm{d}$ post-challenge. Blood samples were taken from the wing vein and centrifuged $(3,000 \times \mathrm{g}, 10 \mathrm{~min})$ at $4{ }^{\circ} \mathrm{C}$, and then the serum was harvested and stored at $-20{ }^{\circ} \mathrm{C}$ until analysis. The birds were then killed by $\mathrm{CO}_{2}$ inhalation and jejunum samples were collected. Two $1 \mathrm{~cm}$ segments of jejunum were collected immediately after slaughter. The segment was located in a distal segment about $5 \mathrm{~cm}$ proximal to the duodenum. The surplus jejunum section was gently flushed with phosphatebuffered saline (PBS) and the mucosa was scraped from the jejunum with a sterile blade and stored in a $1.5 \mathrm{~mL}$ sterile microcentrifuge tube at $-20{ }^{\circ} \mathrm{C}$.

\section{Mucosal cytokines}

Jejunal mucosa ( $0.5 \mathrm{~g}$ per sample) was weighed out, diluted into $4.5 \mathrm{~mL}$ of $0.9 \%$ salt solution, and centrifuged at $6,000 \times \mathrm{g}$ for $15 \mathrm{~min}$. The homogenate was kept on sterile ice and the supernatant was harvested into $1.5 \mathrm{~mL}$ sterile microcentrifuge tubes. The concentrations of interleukin-4 (IL-4) and tumor necrosis factor- $\alpha$ (TNF- $\alpha$ ) were respectively measured using IL-4 (104209) and TNF- $\alpha$ (1041-09) ELISA kits (GBD Ltd, USA) specific for chicken.

\section{Serum endotoxin and diamine oxidase}

The concentrations of serum endotoxin were measured using a limulus amoebocyte lysate (LAL)-based kit (LAL QCL-1000 kit, Lonza, Walkersville, MD). The samples were heated for $10 \mathrm{~min}$ at $70{ }^{\circ} \mathrm{C}$. Internal control for recovery calculation was included in the assessment. Standards and samples were incubated for $10 \mathrm{~min}$ at $37{ }^{\circ} \mathrm{C}$ with LAL and then for another $6 \mathrm{~min}$ with colorimetric substrate. The reaction was stopped with $25 \%$ acetic acid and then the absorbance was read at $405 \mathrm{~nm}$. Diamine oxidase (DAO) activity $(1 \mathrm{ml})$ was examined by a spectrophotometric assay. The DAO standard (batch number D7876-250) was purchased from Sigma.

\section{Jejunalmorphology analysis}

Jejunal segments were flushed with a $0.9 \%$ salt solution, and then fixed with $10 \%$ formaldehyde-phosphate buffer for 48 hours. The formalin-fixed, paraffin-embedded tissues were embedded into Leica EG1160, fixed upon Rotary Microtome (Leica RM2153) and then cut to a thickness of $6 \mu \mathrm{m}$. The tissue segments were dehydrated with Leica HI1220. Slides were stained with hematoxylin and eosin (H\&E; Leica Autostain BRXL) and covered by cover slides. Images were analyzed using software Qwin. Then the 10 longest jejunal villi and lowest jejunal crypts were measured with Olympus AX70 microscope (Olympus Corporation, Tokyo, Japan) and the mean value was calculated. The villus height was measured from the villus-crypt junction to the tip of villus, whereas crypt depth was measured from the root of villus to the lamina propria.

\section{Digestive enzyme activities}

Amylase, lipase, and protease were analyzed using the corresponding kit provided by Jiancheng Bioengineering Institute (Nanjing, China). In brief, the jejunal mucosa was transferred into sterilized tubes containing $10 \mathrm{~mL}$ PBS (7.4 pH), then ultrasonic treatment was applied for $4 \mathrm{~min}$ to dissociate the tissues. The later procedure was accomplished by centrifugation $(5,000 \times \mathrm{g}$ for $25 \mathrm{~min})$. Then the supernatant was used to determine the enzymatic activities following the manufacturer's instructions. 
Table 2 Effects of Clostridium butyricum on growth performance in broilers ${ }^{1}$

\begin{tabular}{|c|c|c|c|c|c|c|c|}
\hline \multirow[t]{2}{*}{ Items } & \multirow{2}{*}{$\begin{array}{l}\text { Age of } \\
(\text { post-ch })^{2}\end{array}$} & \multicolumn{4}{|c|}{ Experimental treats } & \multicolumn{2}{|c|}{ Statistics } \\
\hline & & $\mathrm{NC}$ & PC & $C B$ & CS & SEM & $P$-value \\
\hline \multirow[t]{4}{*}{ BW, g } & $3 d$ & $351.71^{\mathrm{a}}$ & $319.83^{b}$ & $342.23^{a}$ & $339.95^{\mathrm{a}}$ & 3.588 & $<0.01$ \\
\hline & $7 d$ & $401.16^{\mathrm{a}}$ & $354.00^{\mathrm{b}}$ & $402.71^{a}$ & $398.81^{a}$ & 4.479 & $<0.01$ \\
\hline & $14 d$ & $747.33^{\mathrm{ab}}$ & $649.00^{c}$ & $774.83^{\mathrm{a}}$ & $738.16^{\mathrm{b}}$ & 11.161 & $<0.01$ \\
\hline & $21 d$ & $1283.5^{\mathrm{a}}$ & $1064.8^{\mathrm{b}}$ & $1265.8^{\mathrm{a}}$ & $1275.2^{\mathrm{a}}$ & 26.491 & $<0.01$ \\
\hline \multirow[t]{4}{*}{$A D G, g$} & $3-7 d$ & $12.36^{\mathrm{b}}$ & $8.54^{c}$ & $15.12^{\mathrm{a}}$ & $14.71^{a}$ & 0.651 & $<0.01$ \\
\hline & $7-14 d$ & $49.45^{\mathrm{a}}$ & $42.14^{b}$ & $53.16^{a}$ & $48.47^{a}$ & 1.117 & $<0.01$ \\
\hline & $14-21 d$ & 76.60 & 59.40 & 70.13 & 76.72 & 2.831 & 0.089 \\
\hline & $3-21 d$ & $51.76^{\mathrm{a}}$ & $41.38^{b}$ & $51.30^{\mathrm{a}}$ & $51.95^{\mathrm{a}}$ & 1.365 & $<0.01$ \\
\hline
\end{tabular}

\footnotetext{
${ }^{a-c}$ Means in the same row with different superscript letters differ significantly $(P<0.05)$
}

${ }^{1}$ Each mean represents 6 birds. NC = birds fed a basal diet without challenged with $E$. coli K88; PC = birds fed a basal diet and challenged with $E$. coli K88. $\mathrm{CB}=$ birds fed a basal diet including $2 \times 10^{7} \mathrm{CFU}$ C. butyricum/kg of diet and challenged with $E$. coli K88. CS = birds fed a basal diet including 20 mg colistin sulfate/kg of diet and challenged with $E$. coli K88

${ }^{2}$ The days after challenging

\section{Statistical analysis}

One-way ANOVA was performed using SPSS 16.0 Software. Mean values of treatment groups were compared using Duncan's multiple range test with $P<0.05$ considered statistically significant.

\section{Results}

Birds in the PC (positive control) treatment group had less $(P<0.05) \mathrm{BW}$ than the NC (negative control), $\mathrm{CB}$ (C. butyricum), and CS (colistin sulfate) birds from 3 to 21d post-challenge (Table 2). There were no significant differences among the $\mathrm{BW}$ of $\mathrm{NC}, \mathrm{CB}$, and CS groups. The birds of CB group had higher ADG than those fed the $\mathrm{PC}$ diet during 3-7, 7-14, and 3-21 d post-challenge. No significant differences in BW and ADG were observed among the birds of $\mathrm{NC}, \mathrm{CB}$, and $\mathrm{CS}$ groups except that the $\mathrm{ADG}$ of $\mathrm{CB}$ and $\mathrm{CS}$ broilers was higher than the broilers of the $\mathrm{NC}$ groups in 3-7 $\mathrm{d}$ post-challenge.

Birds in CB treatment had higher $(P<0.05)$ concentration of jejunal mucosa TNF- $\alpha$ than those in NC or PC treatment at $3 \mathrm{~d}$ post-challenge, and higher $(P<0.05)$ concentration of TNF- $\alpha$ than PC birds at $7 \mathrm{~d}$ postchallenge (Table 3). There was no significant difference in the concentration of TNF- $\alpha$ between CB and CS birds during the whole experiment. In comparison to $\mathrm{PC}$ birds, CB birds had greater $(P<0.05)$ concentration of jejunal mucosa IL-4 on 14 d post-challenge. No significant differences were observed in the concentration of IL-4 among $\mathrm{CB}, \mathrm{NC}$, and $\mathrm{CS}$ treatments during the whole experiment.

The E. coli challenge significantly increased the concentration of serum endotoxin during the whole experiment (Table 4). Birds in CB treatment had lower $(P<0.05)$ serum endotoxin at $21 \mathrm{~d}$ post-challenge compared with PC birds. There were no significant differences in the concentrations of serum endotoxin between $\mathrm{CB}$ and CS treatment during the whole experiment. The
E. coli challenge significantly increased the concentration of serum DAO during the entire experimental period. Birds in CB treatment had lower $(P<0.05)$ concentration of serum DAO than those in PC treatment at 14 and 21 d post-challenge. No significant differences were found in the concentration of serum DAO between CB and CS treatment group during the course of the experiment.

Birds fed $\mathrm{CB}$ had higher $(P<0.05)$ jejunum villi height than $\mathrm{PC}, \mathrm{NC}$, or $\mathrm{CS}$ birds at 7,14 , and $21 \mathrm{~d}$ postchallenge (Table 5). In comparison to the broilers in PC treatment, broilers in $\mathrm{CB}$ treatment had lower $(P<0.05)$ jejunum crypt depth throughout the experiment. Birds fed CS had lower $(P<0.05)$ jejunum crypt depth compared to $P C$ birds at 7,14 , and $21 \mathrm{~d}$ post-challenge.

The $E$. coli challenge significantly decreased the activity of jejunal mucosa amylase; however, broilers fed with $\mathrm{CB}$ or $\mathrm{CS}$ had increased $(P<0.05)$ amylase activity

Table 3 Effects of Clostridium butyricum on jejunal mucosa cytokines in broilers ${ }^{1}$

\begin{tabular}{|c|c|c|c|c|c|c|c|}
\hline \multirow[t]{2}{*}{ Items } & \multirow{2}{*}{$\begin{array}{l}\text { Age of } \\
(\text { post-ch })^{2}\end{array}$} & \multicolumn{4}{|c|}{ Experimental treats } & \multicolumn{2}{|c|}{ Statistics } \\
\hline & & $\mathrm{NC}$ & $P C$ & $C B$ & CS & SEM & $P$-value \\
\hline \multirow[t]{4}{*}{$\overline{T N F-a, n g / L}$} & $3 d$ & $53.80^{b}$ & $48.88^{b}$ & $76.66^{a}$ & $65.09^{a b}$ & 7.19 & 0.030 \\
\hline & $7 d$ & $65.29^{a b}$ & $53.88^{b}$ & $69.32^{\mathrm{a}}$ & $61.51^{a b}$ & 4.72 & 0.040 \\
\hline & $14 d$ & 63.39 & 50.22 & 62.92 & 61.23 & 6.88 & 0.220 \\
\hline & $21 d$ & 50.56 & 35.28 & 54.46 & 56.92 & 6.92 & 0.110 \\
\hline \multirow[t]{4}{*}{$\mathrm{IL}-4, \mathrm{ng} / \mathrm{L}$} & $3 d$ & 52.52 & 50.9 & 68.7 & 67.51 & 5.78 & 0.140 \\
\hline & $7 d$ & $68.23^{a}$ & $52.16^{b}$ & $62.91^{a b}$ & $57.03^{a b}$ & 3.55 & 0.030 \\
\hline & $14 d$ & $70.65^{\mathrm{a}}$ & $50.46^{b}$ & $69.79^{a}$ & $59.78^{a b}$ & 4.26 & 0.010 \\
\hline & $21 d$ & 52.64 & 42.59 & 56.38 & 57.09 & 6.41 & 0.350 \\
\hline
\end{tabular}

${ }^{\mathrm{a}-\mathrm{c} M e a n s}$ in the same row with different superscript letters differ significantly $(P<0.05)$

${ }^{1}$ Each mean represents 6 birds. NC = birds fed a basal diet without challenged with $E$. coli $\mathrm{K} 88 ; \mathrm{PC}=$ birds fed a basal diet and challenged with $E$. coli K88. $\mathrm{CB}=$ birds fed a basal diet including $2 \times 10^{7} \mathrm{CFU}$ C. butyricum $/ \mathrm{kg}$ of diet and challenged with $E$. coli K88. CS = birds fed a basal diet including 20 mg colistin sulfate/kg of diet and challenged with E. coli K88

${ }^{2}$ The days after challenging 
Table 4 Effects of Clostridium butyricum on the concentrations of serum LPS and DAO in broilers ${ }^{1}$

\begin{tabular}{|c|c|c|c|c|c|c|c|}
\hline \multirow[t]{2}{*}{ Items } & \multirow{2}{*}{$\begin{array}{l}\text { Age of } \\
(\text { post-ch) }\end{array}$} & \multicolumn{4}{|c|}{ Experimental treats } & \multicolumn{2}{|c|}{ Statistics } \\
\hline & & $\mathrm{NC}$ & PC & $\mathrm{CB}$ & CS & SEM & $P$-value \\
\hline \multirow{4}{*}{$\begin{array}{l}\text { Endotoxin, } \\
\mathrm{EU} / \mathrm{mL}\end{array}$} & $3 d$ & $0.460^{b}$ & $0.738^{\mathrm{a}}$ & $0.704^{a}$ & $0.734^{a}$ & 0.025 & $<0.01$ \\
\hline & $7 d$ & $0.455^{\mathrm{b}}$ & $0.640^{a}$ & $0.586^{\mathrm{a}}$ & $0.578^{\mathrm{a}}$ & 0.027 & $<0.01$ \\
\hline & $14 d$ & $0.327^{b}$ & $0.413^{\mathrm{a}}$ & $0.335^{\mathrm{ab}}$ & $0.347^{a b}$ & 0.024 & 0.070 \\
\hline & $21 d$ & $0.252^{c}$ & $0.380^{\mathrm{a}}$ & $0.304^{b c}$ & $0.332^{\mathrm{ab}}$ & 0.023 & $<0.01$ \\
\hline \multirow[t]{4}{*}{$\mathrm{DAO}, \mathrm{U} / \mathrm{mL}$} & $3 d$ & $2.559^{b}$ & $8.823^{\mathrm{a}}$ & $7.493^{\mathrm{a}}$ & $8.056^{\mathrm{a}}$ & 0.498 & $<0.01$ \\
\hline & $7 d$ & $1.570^{b}$ & $8.649^{\mathrm{a}}$ & $7.121^{\mathrm{a}}$ & $7.496^{\mathrm{a}}$ & 0.617 & $<0.01$ \\
\hline & $14 d$ & $1.250^{c}$ & $6.254^{a}$ & $4.194^{b}$ & $4.201^{b}$ & 0.527 & $<0.01$ \\
\hline & $21 d$ & $0.819^{c}$ & $3.952^{\mathrm{a}}$ & $2.419^{b}$ & $3.060^{\mathrm{ab}}$ & 0.424 & $<0.01$ \\
\hline
\end{tabular}

${ }^{\mathrm{a}-\mathrm{c}}$ Means in the same row with different superscript letters differ significantly $(P<0.05)$

${ }^{1}$ Each mean represents 6 birds. NC $=$ birds fed a basal diet without challenged with $E$. coli $\mathrm{K} 88 ; \mathrm{PC}=$ birds fed a basal diet and challenged with E. coli K88. $\mathrm{CB}=$ birds fed a basal diet including $2 \times 10^{7} \mathrm{CFU}$ C. butyricum $/ \mathrm{kg}$ of diet and challenged with $E$. coli $\mathrm{K} 88$. CS = birds fed a basal diet including $20 \mathrm{mg}$ colistin sulfate/kg of diet and challenged with E. coli K88

${ }^{2}$ The days after challenging

compared with broilers in the PC treatment group from 3 to $14 \mathrm{~d}$ post-challenge (Table 6). No significant differences were found in the activities of amylase between $\mathrm{CB}$ and $\mathrm{CS}$ treatments during the whole experiment. Compared with PC birds, the birds in $\mathrm{CB}$ or CS treatments had higher $(P<0.05)$ activities of protease from 3 to $14 \mathrm{~d}$ post-challenge. There were no significant differences in the activity of protease among the four treatment groups at $21 \mathrm{~d}$ post-challenge. Moreover, there were no significant differences between $\mathrm{CB}$ and $\mathrm{NC}$ treatments in the activity of lipase at 3 and $7 \mathrm{~d}$ post-challenge, but those two treatment groups had higher $(P<0.05)$ activity of lipase than PC treatment; and no significant differences in the activity of lipase among the four treatments at 14 and $21 \mathrm{~d}$ postchallenge.

\section{Discussion}

Many reports have showed that probiotics can promote growth performance and improve nutrient utilization efficiency in chickens [6, 25-27], although other studies have also reported that probiotics have no effect on growth performance [28-30]. In contrast, Clostridium butyricum is a probiotic that has been shown to improve growth performance and nutrient utilization efficiency in chickens [20, 21, 31] although Zhang et al. reported that C. butyricum had no effect on broiler performance [16]. In this study we showed that $C$. butyricum improved the BW and ADG of chickens challenged with E. coli K88 compared with broilers in the $\mathrm{PC}$ group, and the broilers in the $\mathrm{CB}$ group showed no significant differences compared to the CS groups on the BW and ADG overall.

Previous reports had shown that probiotics stimulate the immune response [20, 27, 32-34]. Specifically, $C$. butyricum has been shown as capable of influencing the host immune system by modulating cytokine expression [19, 35-37]. C. butyricum could induce the sensitization of the host by increasing pro-inflammatory cytokines such as IL-8, IL-6, and TNF- $\alpha$, and provide beneficial effects to the host by synthesizing the immunosuppressive cytokines such as IL-10 [19, 36, 37]. IL-4 and TNF- $\alpha$ were also secreted by an intracellular signaling cascade in the immune response in response to C. butyricum [38]. Huang et al. [39] reported that Bacillus induced TNF- $\alpha$ in spleens and mesenteric lymph nodes of mice [39]. Lee et al. [30] showed that IL-4 transcripts were increased by B. subtilis strains LSSAO1, Bs278, and Avicorr in broiler chickens [30]. However, Fujiwara et al. [28] reported that supplementation with Bacillus subtilis var. natto fermented soybean did not affect IL-4 gene expression in spleens in broiler chickens [28]. In the present study, chickens fed with C. butyricum had higher concentrations of TNF- $\alpha$ and IL-4. This indicated

Table 5 Effects of Clostridium butyricum on Jejunum morphometry in broilers ${ }^{1}$

\begin{tabular}{|c|c|c|c|c|c|c|c|}
\hline \multirow[t]{2}{*}{ Items } & \multirow{2}{*}{$\begin{array}{l}\text { Age of } \\
(\text { post-ch) })^{2}\end{array}$} & \multicolumn{4}{|c|}{ Experimental treats } & \multicolumn{2}{|c|}{ Statistics } \\
\hline & & $\mathrm{NC}$ & $P C$ & $\mathrm{CB}$ & CS & SEM & $P$-value \\
\hline \multirow[t]{4}{*}{ Villi height, $m$} & $3 d$ & 264.35 & 259.81 & 275.71 & 253.01 & 5.69 & 0.220 \\
\hline & $7 d$ & $267.65^{b c}$ & $287.54^{\mathrm{b}}$ & $346.75^{\mathrm{a}}$ & $254.41^{c}$ & 7.91 & $<0.01$ \\
\hline & $14 d$ & $397.49^{b}$ & $355.07^{c}$ & $448.51^{a}$ & $410.9^{b}$ & 8.24 & $<0.01$ \\
\hline & $21 d$ & $429.41^{b}$ & $433.6^{b}$ & $531.09^{a}$ & $407.26^{\mathrm{b}}$ & 9.37 & $<0.01$ \\
\hline \multirow[t]{4}{*}{ Crypt depth, m } & $3 d$ & $50.22^{a}$ & $47.01^{a b}$ & $33.68^{c}$ & $42.9^{b}$ & 2.08 & $<0.01$ \\
\hline & $7 d$ & $50.06^{b}$ & $60.3^{\mathrm{a}}$ & $39.44^{c}$ & $38.2^{c}$ & 2.17 & $<0.01$ \\
\hline & $14 d$ & $66.07^{b}$ & $73.96^{\mathrm{a}}$ & $56.51^{c}$ & $59.95^{c}$ & 1.87 & $<0.01$ \\
\hline & $21 d$ & $82.5^{\mathrm{b}}$ & $115.46^{\mathrm{a}}$ & $84.04^{b}$ & $76.03^{b}$ & 3.29 & $<0.01$ \\
\hline
\end{tabular}

\footnotetext{
a-c Means in the same row with different superscript letters differ significantly $(P<0.05)$

${ }^{1}$ Each mean represents 6 birds. NC = birds fed a basal diet without challenged with $E$. coli K88; PC = birds fed a basal diet and challenged with $E$. coli K88. $\mathrm{CB}=$ birds fed a basal diet including $2 \times 10^{7} \mathrm{CFU}$ C. butyricum $/ \mathrm{kg}$ of diet and challenged with $E$. coli K88. CS = birds fed a basal diet including 20 mg colistin sulfate/kg of diet and challenged with E. coli K88

${ }^{2}$ The days after challenging
} 
Table 6 Effects of Clostridium butyricum on digestive enzyme activities in broilers ${ }^{1}$

\begin{tabular}{|c|c|c|c|c|c|c|c|}
\hline \multirow[t]{2}{*}{ Items } & \multirow{2}{*}{$\begin{array}{l}\text { Age of } \\
(\text { day post-ch) }\end{array}$} & \multicolumn{4}{|c|}{ Experimental treats } & \multicolumn{2}{|c|}{ Statistics } \\
\hline & & NC & PC & $\mathrm{CB}$ & $\mathrm{CS}$ & SEM & $P$-value \\
\hline \multirow[t]{4}{*}{ Amylase, U/mgprot } & $3 d$ & $0.94^{\mathrm{a}}$ & $0.33^{c}$ & $0.70^{b}$ & $0.74^{\mathrm{ab}}$ & 0.058 & $<0.01$ \\
\hline & $7 d$ & $0.96^{\mathrm{a}}$ & $0.45^{\mathrm{b}}$ & $0.88^{\mathrm{a}}$ & $0.83^{\mathrm{a}}$ & 0.054 & $<0.01$ \\
\hline & $14 d$ & $0.80^{\mathrm{a}}$ & $0.60^{b}$ & $0.87^{\mathrm{a}}$ & $0.78^{\mathrm{a}}$ & 0.033 & 0.018 \\
\hline & $21 d$ & $0.91^{\mathrm{a}}$ & $0.75^{\mathrm{b}}$ & $0.79^{\mathrm{ab}}$ & $0.85^{\mathrm{ab}}$ & 0.027 & 0.112 \\
\hline \multirow[t]{4}{*}{ Protease, U/mgprot } & $3 d$ & $106.86^{\mathrm{a}}$ & $54.66^{c}$ & $76.92^{\mathrm{b}}$ & $80.10^{\mathrm{b}}$ & 5.080 & $<0.01$ \\
\hline & $7 d$ & $103.76^{\mathrm{a}}$ & $65.29^{b}$ & $93.32^{\mathrm{a}}$ & $89.39^{a}$ & 4.213 & $<0.01$ \\
\hline & $14 d$ & $98.17^{\mathrm{a}}$ & $67.04^{b}$ & $93.60^{a}$ & $91.46^{a}$ & 3.975 & 0.014 \\
\hline & $21 d$ & 130.76 & 109.06 & 133.03 & 125.01 & 4.648 & 0.264 \\
\hline \multirow[t]{4}{*}{ Lipase, U/mgprot } & $3 d$ & $190.87^{\mathrm{ab}}$ & $105.14^{c}$ & $154.02^{b}$ & $205.53^{\mathrm{a}}$ & 10.833 & $<0.01$ \\
\hline & $7 d$ & $193.84^{\mathrm{a}}$ & $105.66^{b}$ & $186.09^{\mathrm{a}}$ & $155.90^{\mathrm{ab}}$ & 10.800 & $<0.01$ \\
\hline & $14 d$ & 183.76 & 167.93 & 205.40 & 195.76 & 7.046 & 0.278 \\
\hline & $21 d$ & 194.07 & 177.85 & 197.87 & 203.41 & 5.697 & 0.448 \\
\hline
\end{tabular}

a-c Means in the same row with different superscript letters differ significantly $(P<0.05)$

${ }^{1}$ Each mean represents 6 birds. NC = birds fed a basal diet without challenged with $E$. coli $\mathrm{K} 88$; $\mathrm{PC}=$ birds fed a basal diet and challenged with $E$. coli K88.

$\mathrm{CB}=$ birds fed a basal diet including $2 \times 10^{7} \mathrm{CFU}$ C. butyricum $/ \mathrm{kg}$ of diet and challenged with $E$. coli $\mathrm{K} 88$. CS = birds fed a basal diet including 20 mg colistin sulfate/ $\mathrm{kg}$ of diet and challenged with E. coli K88

${ }^{2}$ The days after challenging

that $C$. butyricum influenced the immune response in broiler chickens challenged with E. coli K88.

Lipopolysaccharide (LPS) is an integral component of the outer cell membranes of Gram-negative bacteria which are shed from the bacteria when cell lysis occurs [40]. E. coli K88 produces LPS [41], which induced endotoxic shock by triggering the systemic inflammatory response [42-45]. The endotoxins from LPS induce a degenerative morphology and the destruction of lymphocytes in birds [46]. Moreover, endotoxin is associated with intestinal permeability [47-49]. When gut permeability is increased, the endotoxin will translocate from the gut into circulation. Ait-Belgnaoui et al. [48] reported that L. farciminis treatment prevented stressinduced peripheral endotoxin in rats [48]. DAO is localized mainly in the small intestinal mucosa, particularly near the tips of villi and reflects small intestinal integrity and maturity [50-52]. Intestinal mucosal damage causes leakage of DAO from small intestinal villus tips into the circulation, so DAO is an index of intestinal mucosal barriers [52-54]. Zhang et al [35] reported that the serum level of DAO in allergic mice was markedly higher than that in control mice [35]. Synbiotic therapy prevented HR-related decrease of intestinal integrity that was indicated by the reduction in serum DAO activity [55] and returned serum DAO activities to normal levels after hepatectomy in humans [56]. Zhou et al. reported that Lactobacillus plantarum significantly lowered the plasma DAO activities in the bile duct ligation rat model [57]. Sun et al [58] reported that probiotics relatively decreased the levels of LPS and DAO in rats compared with the cardiopulmonary bypass (CPB)-operated ones [58]. In this study, dietary supplementation of C. butyricum decreased serum endotoxin and DAO in E. colichallenged birds. Our results indicated that CB benefits the intestinal barrier function in broiler chickens challenged with E.coli $\mathrm{K} 88$.

The length of villi and the depth of crypt are the important morphological parameters, and are considered as indicators of optimal intestinal functions. The previous studies showed that dietary supplementation with probiotics increased the villus height and villus height: crypt depth ratio, decreased the crypt depth in broiler chickens [59-64]. Our previous research also showed that birds fed C. butyricum had higher ileal villus height and lower ileal crypt depth [31]. The present study showed that dietary supplementation with $C B$ increased the jejunal villus height and decreased the crypt depth in broiler chickens challenged with E.coli K88. The current result demonstrated that $C$. butyricum improved the structure and function of intestinal mucosa in E.coli infected condition.

Amylase, lipase, and protease play very important roles in the digestion of nutrient materials. Reports on the efficacy of probiotics on the digestive enzymes have been varied. Rajput et al. [34, 65] reported that Saccharomyces boulardii supplementation increased the activity of lipase, but had no significant improvement in amylase and trypsin in the jejunum of broiler chickens [65]. Wang and $\mathrm{Gu}$ [26] reported that the probiotic Bacillus coagulans NJ0516 increased the activities of protease and amylase but had no effect on the activities of lipase in 
broilers [26]. However, de Lima et al. [29] reported that the addition of the probiotic Bacillus subtilis in the diet did not affect digestive enzymes activities in broiler chickens [29]. The present study indicated that dietary supplementation of C. butyricum promoted digestive enzyme activities in broiler chickens challenged with E. coli K88. This was likely due to $C$. butyricum-induced protection of the intestinal integrity by inhibiting the activities of E. coli K88 and LPS, so augmented the activities of these enzymes. It is also possible that $C$. butyricum is capable of directly producing digestive enzymes in the gut of animals.

\section{Conclusion}

The results of our study indicated that E. coli K88 challenge lowered the BW and ADG, decreased the intestinal barrier function and digestive enzyme activities, but dietary supplementation of $C$. butyricum reversed these observations and promoted the immune response, improved intestinal barrier function and digestive enzyme activities in broiler chickens challenged with $E$. coli K88. Our results suggest that including $C$. butyricum in poultry diets has the potential for rearing healthier birds. There was no significant difference between the $C$. butyricum probiotic treatment and the colistin sulfate antibiotic treatment on the effect of growth performance, immune response, intestinal barrier function, and digestive enzyme activity in broiler chickens challenged with Escherichia coli. Therefore, the C. butyricum probiotic may be an alternative to antibiotic for animal production.

\footnotetext{
Abbreviations

C. butyricum: Clostridium butyricum; E. coli K88: Escherichia coli K88 NC: negative control treatment; PC: positive control treatment; CB: C. butyricum probiotic treatment; CS: Colistin sulfate antibiotic treatment; BW: body weight; ADG: average day gain; TNF-a: tumor necrosis factor-a; IL-4: interleukin-4; DAO: Diamine oxidase.
}

\section{Competing interests}

The authors have declared that no competing interests exist.

\section{Authors' contributions}

LZ and LLZ carried out the animal experiments and data analysis, and drafted the manuscript. CMY and XAZ designed the study and revised the manuscript. LZ and GTC participated in the animal trial. XFZ helped with data collection and analysis. All authors read and approved the final manuscript.

\section{Acknowledgements}

This work was supported by the International Cooperation Project of Zhejiang Province (No. 2012C14031) and Innovative Research Team Program of Zhejiang Province (No. 2011R50025).

\section{Author details}

${ }^{1}$ College of Animal Sciences, Zhejiang University, Hangzhou 310058, China. ${ }^{2}$ College of Animal Science and Technology, Zhejiang A \& F University, 88 North Huancheng Road, Lin'an, Zhejiang 311300, China. ${ }^{3} Z$ hejiang Huijia Biological Technology Ltd., Anji 313307, China.

Received: 24 August 2015 Accepted: 11 January 2016

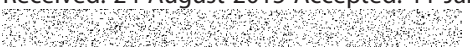

\section{References}

1. Huff WE, Huff GR, Rath NC, Balog JM, Donoghue AM. Prevention of Escherichia coli infection in broiler chickens with a bacteriophage aerosol spray. Poult Sci. 2002;81(10):1486-91.

2. Abu-Basha EA, Gharaibeh SM, Thabet AM. In vitro susceptibility of resistant Escherichia coli field isolates to antimicrobial combinations. J Appl Poultry Res. 2012;21(3):595-602.

3. Barros MR, da Silveira WD, de Araujo JM, Costa EP, Oliveira AAD, Santos APDF, et al. Antimicrobial resistance and plasmidial profile of Escherichia coli strain isolated from broilers and commercial layers in the state of Pernambuco, Brazil. Pesq Vet Bras. 2012;32(5):405-10.

4. Zhang T, Wang CG, LV JC, Wang RS, Zhong XH. Survey on tetracycline resistance and antibiotic-resistant genotype of avian Escherichia coli in North China. Poult Sci. 2012;91(11):2774-7.

5. Al-Bahry SN, Al-Mashani BM, Al-Ansari AS, Elshafie AE, Mahmoud IY. Escherichia coli tetracycline efflux determinants in relation to tetracycline residues in chicken. Asian Pac J Trop Med. 2013;6(9):718-22.

6. Zhang C, Li FY, Liu WH, Zou L, Yan C, Lu K, et al. T4-Like Phage Bp7, a Potential Antimicrobial Agent for Controlling Drug-Resistant Escherichia coli in Chickens. Appl Environ Microbiol. 2013;79(18):5559-65.

7. Laube H, Friese A, von Salviati C, Guerran B, Käsbohrer A, Kreienbrock L, et al. Longitudinal Monitoring of Extended-Spectrum-Beta-Lactamase /AmpCProducing Escherichia coli at German Broiler Chicken Fattening Farms. Appl Environ Microbiol. 2013;79(16):4815-20.

8. Anadon A, Martinez-Larranaga MR, Aranzazu Martinez M. Probiotics for animal nutrition in the European Union. Regulation and safety assessment. Regul Toxicol Pharmacol. 2006;45(1):91-5.

9. Huff GR, Huff WE, Rath NC, Solis De Los Santos F, Farnell MB, Donoghue AM. Influence of hen age on the response of turkey poults to cold stress, Escherichia coli challenge, and treatment with a yeast extract antibiotic alternative. Poult Sci. 2007:86(4):636-42.

10. Cartman ST, La Ragione RM, Woodward MJ. Bacillus subtilis spores germinate in the chicken gastrointestinal tract. Appl Environ Microbiol. 2008;74(16):5254-8.

11. Williams LD, Burdock GA, Jimenez G, Castillo M. Literature review on the safety oftoyocerin, a non-toxigenic and non-pathogenic Bacillus cereus var. toyoi preparation. Regul Toxicol Pharmacol. 2009;55(2):236-46.

12. Higgins JP, Higgins SE, Wolfenden AD, Henderson SN, Torres-Rodriguez A, Vicente $J$, et al. Effect of lactic acid bacteria probiotic culture treatment timing on Salmonella Enteritidis in neonatal broilers. Poult Sci. 2010;89(2):243-7.

13. Higgins SE, Wolfende AD, Tellez G, Hargis BM, Porter TE. Transcriptional profiling of cecal gene expression in probiotic-and Salmonella-challenged neonatal chicks. Poult Sci. 2011;90(4):901-13.

14. Tellez G, Pixley C, Wolfenden RE, Layton SL, Hargis BM. Probiotics/direct fed microbials for Salmonella control in poultry. Food Res Int. 2012; 45(2):628-33

15. Huff GR, Huff WE, Jalukar S, Oppy J, Rath NC, Packialakshmi B. The effects of yeast feed supplementation on turkey performance and pathogen colonization in a transport stress/Escherichia coli challenge. Poult Sci. 2013; 92(3):655-62.

16. Zhang BK, Yang X, Guo YM, Long FY. Effects of dietary lipids and Clostridium butyricum on the performance and the digestive tract of broiler chickens. Arch Anim Nutr. 2011;65(4):329-39. a.

17. Meimandipour A, Shuhaimi M, Soleimani AF, SAzhar K, Hair-Bejo M, Kabeir BM, et al. Selected microbial groups and short-chain fatty acids profile in a simulated chicken cecum supplemented with two strains of Lactobacillus. Poult Sci. 2010;89(3):470-6.

18. Kong Q, He GQ, Jia JL, Zhu QL, Ruan H. Oral administration of Clostridium butyricum for modulating gastrointestinal microflora in mice. Curr Microbiol. 2011;62(2):512-7.

19. Gao QX, Qi LL, Wu TX, Wang JB. Clostridium butyricum activates TLR2mediated MyD88-independent signaling pathway in HT-29 cells. Mol Cell Biochem. 2012;361(1-2):31-7. b.

20. Yang CM, Cao GT, Ferket PR, Liu TT, Zhou L, Zhang L, et al. Effects of probiotic, Clostridium butyricum, on growth performance, immune function, and cecal microflora in broiler chickens. Poult Sci. 2012;91(9):2121-9.

21. Zhao X, Guo YM, Guo SS, Tan JZ. Effects of Clostridium butyricum and Enterococcus faecium on growth performance, lipid metabolism, and cecal microbiota of broiler chickens. Appl Microbiol Biotechnol. 2013; 97(14):6477-88 
22. Yang X, Zhang B, Guo Y, Jiao P, Long F. Effects of dietary lipids and Clostridium butyricum on fat deposition and meat quality of broiler chickens. Poult Sci. 2010;89(2):254-60.

23. Zhang B, Yang X, Guo Y, Long F. Effects of dietary lipids and Clostridium butyricum on serum lipids and lipid-related gene expression in broiler chickens. Animal. 2011;5(12):1909-15.

24. Gao QX, Qi LL, Wu TX, Wang JB. Ability of Clostridium butyricum to inhibit Escherichia coli-induced apoptosis in chicken embryo intestinal cells. Vet Microbiol. 2012;160(3):395-402. a.

25. Alkhalf A, Alhaj M, Al-homidan I. Influence of probiotic supplementation on blood parameters and growth performance in broiler chickens. Saudi J Biol Sci. 2010;17(3):219-25.

26. Wang Y, Gu Q. Effect of probiotic on growth performance and digestive enzyme activity of Arbor Acres broilers. Res Vet Sci. 2010;89(2):163-7.

27. Salim HM, Kang HK, Akter N, Kim DW, Kim JH, Kim MJ, et al. Supplementation of direct-fed microbials as an alternative to antibiotic on growth performance, immune response, cecal microbial population, and ileal morphology of broiler chickens. Poult Sci. 2013;92(8):2084-90.

28. Fujiwara K, Yamazaki M, Abe H, Nakashima K, Yakabe Y, Otsuka M, et al. Effect of Bacillus subtilis var. natto fermented soybean on growth performance, microbial activity in the caeca and cytokine gene expression of domestic meat type chickens. J Poult Sci. 2009;46(2):116-22.

29. Lima ACF, PizauroJúnior JM, Macari M, Malheiros EB. Effect of probiotic supplementation on performance and digestive enzymes activity of broiler chickens[J]. Rev Bras Zootec. 2003;32(1):200-7.

30. Lee KW, Lee SH, Lillehoj HS, Li GX, Jang SI, Babu US, et al. Effects of directfed microbials on growth performance, gut morphometry, and immune characteristics in broiler chickens. Poult Sci. 2010;89(2):203-16.

31. Cao GT, Xiao YP, Yang CM, Chen AG, Liu TT, Zhou L, et al. Effects of clostridium butyricum on growth performance, nitrogen metabolism, intestinal morphology and cecal microflora in broiler chickens. J Anim Vet Adv. 2012;11(15):2665-71.

32. Rajput IR, Li WF, Li YL, Jian L, Wang MQ. Application of probiotic (Bacillus subtilis) to enhance immunity, antioxidation, digestive enzymes activity and hematological profile of Shaoxing duck. Pakistan Veterinary Jounal. 2012; 33(1):69-72.

33. Cao GT, Zeng XF, Chen AG, Zhou L, Zhang $L$, Xiao YP, et al. Effects of a probiotic, Enterococcus faecium, on growth performance, intestinal morphology, immune response, and cecal microflora in broiler chickens challenged with Escherichia coli K88. Poult Sci. 2013:92(11):2949-55.

34. Rajput IR, Li YL, Xin X, Wu BB, Juan ZL, Cui ZW, et al. Effect of saccharomyces boulardii and bacillus subtilis B10 on intestinal ultrastructure modulation and mucosal immunity development mechanism in broiler chickens. Poult Sci. 2013;92(4):956-65.

35. Zhang HQ, Ding TT, Zhao JS, Yang X, Zhang HX, Zhang JJ, et al. Therapeutic effects of clostridium butyricum on experimental colitis induced by oxazolone in rats. World J Gastroenterol. 2009:15(15):1821-8.

36. Hua MC, Lin TY, Lai MW, Kong MS, Chang HJ, Chen CC. Probiotic Bio-Three induces Th1 and anti-inflammatory effects in PBMC and dendritic cells. World J Gastroenterol. 2010;16(28):3529-40.

37. Gao QX, Qi LL, Wu TX, Xia TT, Wang JB. Immunomodulatory effects of Clostridium butyricum on human enterocyte-like HT-29 cells. Anim Cells Syst. 2013;17(2):121-6.

38. Rodes L, Afshan K, Arghya P, Michael CC, Daniel M, Catherine TD, et al. Effect of probiotics lactobacillus and bifidobacterium on gutderived lipopolysaccharides and inflammatory cytokines: an in vitro study using a human colonic microbiota model. J Microbiol Biotechnol. 2013;23(4):518-26.

39. Huang JM, La RM, Nunez A, Cutting SM. Immunostimulatory activity of Bacillus spores. FEMS Immunol Med Microbiol. 2008:53(2):195-203.

40. McCuskey RS, Urbaschek R, Urbaschek B. The microcirculation during endotoxemia. Cardiovasc Res. 1996;32(4):752-63.

41. Hsu CB, Lee JW, Huang HJ, Wang CH, Lee TT, Yen HT, et al. Effects of Supplemental Glutamine on Growth Performance, Plasma Parameters and LPS-induced Immune Response of Weaned Barrows after Castration. AsianAustralasian journal of animal sciences. 2012;25(5):674.

42. Sweet MJ, Hume DA. Endotoxin signal transduction in macrophages. J Leukoc Biol. 1996;60(1):8-26.

43. King MR, Wester TJ, Morel PCH. The effect of dietary spray-dried bovine colostrum and plasma on the response of pigs to enterotoxigenic E. coli challenge after weaning. Livest Sci. 2007;108(1):292-4.
44. Liu P, Piao XS, Thacker PA, Zeng ZK, Li PF, Wang D, et al. Chitooligosaccharide reduces diarrhea incidence and attenuates the immune response of weaned pigs challenged with Escherichia coli K88. J Anim Sci. 2010;88(12):3871-9.

45. Shimazu T, Villena J, Tohno M, Fujie H, Hosoya S, Shimosato T, et al. Immunobiotic Lactobacillus jensenii elicits anti-inflammatory activity in porcine intestinal epithelial cells by modulating negative regulators of the Toll-like receptor signaling pathway. Infect Immun. 2012;80(1):276-88.

46. Shini S, Kaiser P, Shini A, Bryden WL. Differential alterations in ultrastructural morphology of chicken heterophils and lymphocytes induced by corticosterone and lipopolysaccharide. Vet Immunol Immunopathol. 2008; 122(1):83-93.

47. Opal SM, Scannon PJ, Vincent JL, White M, Carroll SF, Palardy JE, et al. Relationship between plasma levels of lipopolysaccharide (LPS) and LPSbinding protein in patients with severe sepsis and septic shock. J Infect Dis. 1999;180(5):1584-9.

48. Ait-Belgnaoui A, Durand H, Cartier C, Chaumaz G, Eutamene H, Ferrier L, et al. A Prevention of gut leakiness by a probiotic treatment leads to attenuated HPA response to an acute psychological stress in rats. Psychoneuroendocrinology. 2012;37(11):1885-95.

49. Bose $\mathrm{S}$, Jeon S, Eomb T, Song MY, Kim H. Evaluation of the in vitro and in vivo protective effects of unfermented and fermented Rhizomacoptidis formulations against lipopolysaccharide insult. Food Chem. 2012;135(2):452-9.

50. Hesterberg R, Sattleb J, Lorenz W, Stahlknecht CD, Barth H, Crombach M, et al. Histamine content, diamine oxidase activity and histamine methyl transferase activity in human tissues: Fact or fictions? Agents Actions. 1984; 14(3-4):324-34.

51. Dagostino L, Daniele B, Pignata S, Greco L, Mazzacca G. Postheparin plasma diamine oxidase in subjects with small bowel disease, diagnostic efficiency of a simplified test. Digestion. 1988;41(1):46-54.

52. Wolvekamp MCJ, De Bruin RWF. Diamine oxidase: an overview of historical, biochemical and functional aspects. Dig Dis. 1994;12(1):2-14.

53. Moriyama $K$, Kouchi $Y$, Morinaga $H$, Irimura $K$, Hayashi $T$, Ohuchida A, et al, Diamine oxidase, a plasma biomarker in rats to $\mathrm{Gl}$ tract toxicity of oral fluorouracil anti-cancer drugs. Toxicology. 2006;217(2):233-9.

54. Tsunooka N, Maeyama K, Nakagawa H, Doi T, Horiuchi A, Miyauchi K, et al. Localization and changes of diamine oxidase during cardiopulmonary bypass in rabbits. J Surg Res. 2006;131(1):58-63.

55. Usami M, Miyoshi M, Kanbara Y, Aoyama M, Sakaki H, Shuno K, et al. Effects of perioperative synbiotic treatment on infectious complications, intestinal integrity, and fecal flora and organic acids in hepatic surgery with or without cirrhosis. J Parenter Enter Nutr. 2011;35(3):317-28.

56. Sugawara G, Nagino M, Nishio H, Ebata T, Takagi K, Asahara T, et al. Perioperative synbiotic treatment to prevent postoperative infectious complications in biliary cancer surgery: a randomized controlled trial. Ann Surg. 2006;244(5):706-14

57. Zhou YK, Qin HL, Zhang M, Shen TY, Chen HQ, Ma YL, et al. Effects of Lactobacillus plantarum on gut barrier function in experimental obstructive jaundice. World J Gastroenterol. 2012;18(30):3977-91.

58. Sun YJ, Cao HJ, Song DD, Diao YG, Zhou J, Zhang TZ. Probiotics Can Alleviate Cardiopulmonary Bypass-Induced Intestinal Mucosa Damage in Rats. Dig Dis Sci. 2013;58(6):1528-36.

59. Gunal M, Yayli G, Kaya O, Karahan N, Sulak O. The effects of antibiotic growth promoter, probiotic or organic acid supplementation on performance, intestinal microflora and tissue of broilers. Int J Poultry Sci. 2006:5(2):149-55.

60. Samli HE, Senkoylu N, Koc F, Kanter M, Agma A. Effects of Enterococcus faecium and dried whey on broiler performance, gut histomorphology and intestinal microbiota. Arch Anim Nutr. 2007;61(1):42-9.

61. Awad WA, Ghareeb K, Abdel-Raheem S, Böhm J. Effects of dietary inclusion of probiotic and synbiotic on growth performance, organ weights, and intestinal histomorphology of broiler chickens. Poult Sci. 2009;88(1):49-56.

62. Taheri HR, Moravej H, Malakzadegan A, Tabandeh F, Zaghari M, Shivazad M, et al. Efficacy of Pediococcusacidlactici-based probiotic on intestinal Coliforms and villus height, serum cholesterol level and performance of broiler chickens. Afr J Biotechnol. 2010;9(44):7564-7.

63. Kim JS, Ingale SL, Kim YW, Kim KH, Sen S, Ryu MH, et al. Effect of supplementation of multi-microbe probiotic product on growth performance, apparent digestibility, cecalmicrobiota and small intestinal morphology of broilers. J Anim Physiol Anim Nutr. 2012;96(4):618-26. 
64. Sen S, Ingale SL, Kim YW, Kim JS, Kim KH, Lohakare JD, et al. Effect of supplementation of Bacillus subtilis LS 1-2 to broiler diets on growth performance, nutrient retention, caecal microbiology and small intestinal morphology. Res Vet Sci. 2012;93(1):264-8.

65. Rajput IR, Li YL, Xu X, Huang Y, Zhi WC, Yu DY, et al. Supplementary effects of Saccharomyces boulardii and Bacillus subtilis B10 on digestive enzyme activities, antioxidation capacity and blood homeostasis in broiler. International Journal of Agriculture \& Biology. 2013;15(2):231-7.

Submit your next manuscript to BioMed Central and we will help you at every step:

- We accept pre-submission inquiries

- Our selector tool helps you to find the most relevant journal

- We provide round the clock customer support

- Convenient online submission

- Thorough peer review

- Inclusion in PubMed and all major indexing services

- Maximum visibility for your research

Submit your manuscript at www.biomedcentral.com/submit 